\title{
Mineral fertilizer market consumption trends
}

\author{
Natalya V. Dyuzheva, Arina A. Tinkova \\ Peoples' Friendship University of Russia (RUDN University) \\ 6 Miklukho-Maklaya St., Moscow, 117198, Russian Federation
}

\begin{abstract}
The research renders the analysis of the trends in the global mineral fertilizer market. The study aims to define the factors that correlate with fertilizer consumption. Objectives of the study are to analyze the dynamics and structure of demand, supply, foreign trade, market factors, and characteristics, and forecast its development; to analyze the correlation between fertilizer consumption, arable land scale, cereal yield; to study the phenomenon of mineral fertilizer consumption in Russia. The paper answers the question, where is the fertilizer consumption concentrated, and why? The defined market producers are China, Russia; the global consumers are Brazil, India, China, and the USA. The countries with the highest cereal yield in the world do not coincide with the largest fertilizer consumer countries. Cereal yield and the level of fertilizer application per hectare of arable land in the most significant mineral fertilizer consumer countries are not directly correlated. The countries with the highest cereal yield are mostly well developed with relatively small arable lands. Most of them have soil which is unsuitable for farming. When arable land scale (hectares) rises on $1 \%$, the fertilizer consumption increases by $0.7 \%$, with a probability of $99 \%$. According to this model, Russia consumes 10569 thousand tons of its estimated volume. The data were classified using Excel and analyzed via econometric modeling software Eviews.
\end{abstract}

Keywords: mineral fertilizer, market trend, international trade, yield, consumption

\section{Introduction}

The planet's population is growing, but each year there are fewer lands that can be used as the new arable land. In these terms, the role of mineral fertilizers is increasing, because it correlates with the crop yields. The development of a sustainable food system is becoming one of the main tasks of the world community. Increasing crop yields is one of the main ways to ensure food security. All this means that the global demand for mineral fertilizers, which once made a revolution in agriculture, will grow. In these terms, both exporters and importers need to follow the global mineral fertilizer market trends. It is clear that the highest demand nowadays is in countries with a significant population, but the population volume is not the only factor in fertilizer consumption.

The purpose of this article is to identify the characteristics of the world market of mineral fertilizers. The article is divided into two parts: the first part identifies the main characteristics of the global market of mineral fertilizers (demand,

(C) Dyuzheva N.V., Tinkova A.A., 2019

(c) () This work is licensed under a Creative Commons Attribution 4.0 International License https://creativecommons.org/licenses/by/4.0/ 
supply, import, and export) in dynamics in three segments: nitrogen, phosphate, and potash. Factors affecting the world market conditions are the following: factors of production distribution, demand factors, factors of dependence on foreign trade in mineral fertilizers. The second part is an analysis of the relationship between fertilizer consumption and cereal yield: the correlation between the following indicators: aggregate fertilizer consumption by the country, consumption per hectare of arable land ( $\mathrm{kg} / \mathrm{ha})$, as well as aggregate and weighted $(\mathrm{kg} / \mathrm{ha})$ cereal yield. The model of the correlation between fertilizer consumption and arable land scale was evaluated. In conclusion, the paper gives the model's practical application case study.

\section{Literature review}

The information and statistical base of the study are data and analytics provided by the World Bank and International Fertilizer Association (IFA), as well as analytical materials from the Food and Agriculture Organization of the United Nations (FAO UN).

The mineral fertilizer market is usually analyzed by three segments: nitrogen, phosphate, and potash (Rodionova, 2010). Furthermore, the yield analysis is often provided by both the type of fertilizer and the plant (Mazurova, 2018). Moreover, although the scientific works of N.V. Falina, D.O. Dyukarev, and U.B. Nazarbek represent the general characteristics of the mineral fertilizers market, nevertheless, rethinking their visions played a role in achieving the goals and objectives of this study. This article discusses the specific consumption features of the global mineral fertilizer market.

\section{Research methodology}

The period of the analysis is 1961 till 2017, which is the first and the available last year according to IFA data. The research is based on econometric methods, comparative, and correlation analysis. The data were classified using Excel and analyzed via econometric modeling software Eviews.

\section{Mineral fertilizer market trends}

The demand for mineral fertilizers from 1961 to 2017 increased six times (Figure 1). This is due to the rise in arable lands and the need to improve soil fertility in the context of global population growth. The primary consumers of mineral fertilizers are China, India, the USA, Brazil, and Indonesia. In 2016, China accounted for almost $30 \%$ of the total global consumption of mineral fertilizers, whereas India and the United States consume half as China. The USA, India, and China account for more than $50 \%$ of the world's total consumption, which is associated with a growing population in these countries.

Nitrogen fertilizers are the most consumed in the world among other segments due to the variety of product mix and relative cheapness compared to other mineral fertilizers. The share of the 11 most significant consumers of nitrogen fertilizers in the total volume of consumption is $75 \%$. As for potash fertilizers, China, Brazil, and the United States account for more than half of the demand. In Russia, which is one of the largest suppliers of potash fertilizers, this product is not in 
demand. In turn, the three most significant consumers of phosphate fertilizers China, India, and Brazil - account for about $70 \%$ of the global consumption of phosphate fertilizers.

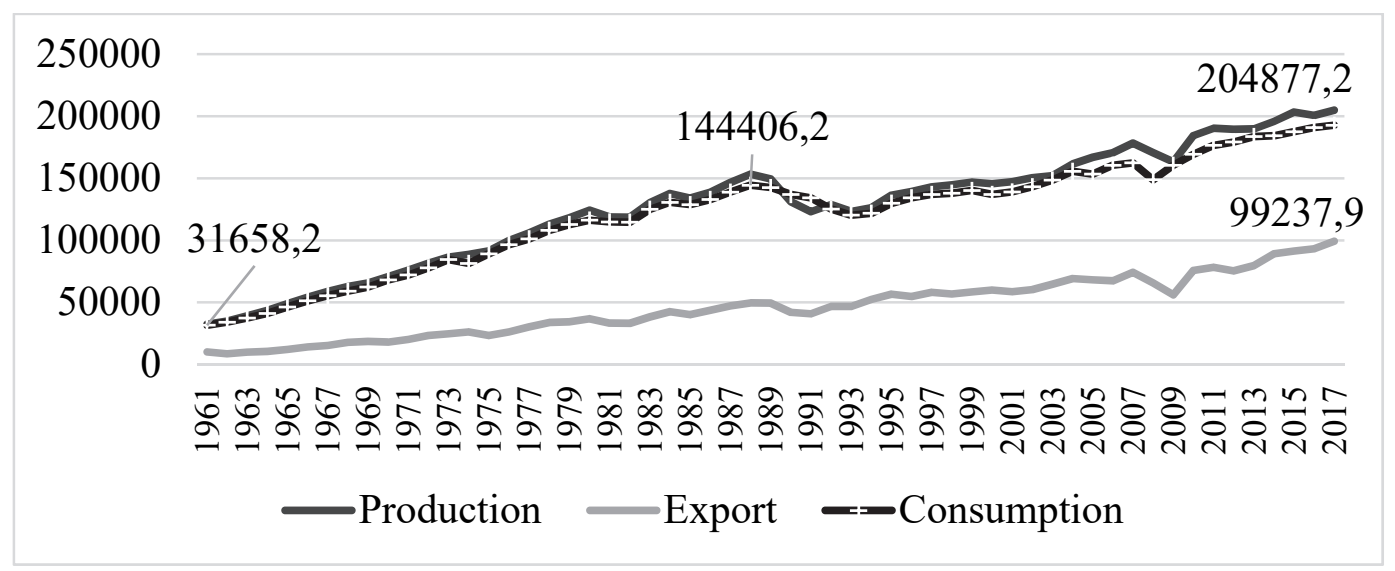

Figure1. Dynamics of mineral fertilizer demand and supply, 1991-2017, ths. tons

Source: International Fertilizer Association database. http://ifadata.fertilizer.org/ucSearch.aspx (accessed: 09.07.2019).

The largest importer of mineral fertilizers in 2017 was the United States, with the $13 \%$ share of the total fertilizer imports of the world. In the second and third places are Brazil and India, with a $12 \%$ share. The share of imports in the domestic consumption of the most abundant mineral fertilizer importers in 2017 is averagely more than 70 percent. However, the exceptions are the USA, India, China, and Canada, which are also producers of mineral fertilizers, so consumption is not so heavily dependent on imports. India's average share of mineral fertilizer imports in domestic consumption is $38 \%$.

In 2017, the volume of world production of mineral fertilizers reached 204 million tons, which is 1,5 times more than in 2000 and 6 times more than in 1961. At the same time, there are significant shifts in the production location due to factors that vary depending on the type of fertilizer. The fundamental principles when placing production are the availability of production factors and closeness to the consumer. For example, the energy intensity of production plays a crucial role in the case of nitrogen fertilizers, closeness to the consumer is the determining factor for phosphorus fertilizers and the presence of a rare non-transportable raw material base for potash fertilizers. There has been a rapid increase in the production of mineral fertilizers in developing countries over the past 15 years. The most massive mineral fertilizer production volume in developed countries was last seen in 1988, after which there has been a sharp decline. It remained low over the last 25 years. In 1961 Western and Central Europe supplied 50\% of the total market. Currently, their share has fallen to $8 \%$. The location of the mineral fertilizer's production moves to densely populated regions and countries where the bulk of world crop production is situated. In other words, production approached the regions of the industry's product's consumption (Bleiman, Burkov, 2017).

The three largest producers provide half of the global mineral fertilizer market. China produces the most significant share that equals 30\%. Russia takes se- 
cond place with a share three times less than China and equals to $9 \%$. India is the third producer with a $9 \%$ share. The share of the 20 largest producers of mineral fertilizers in 2017, accounts for about $90 \%$ of world production.

In 2017 China and Russia were the largest exporters of mineral fertilizers (17\% of world exports). Canada is in third place with a share of $14 \%$. The three largest exporters account for half of the total exports of mineral fertilizers in the world. TOP 20 exporting countries share in total sector exports is $90 \%$.

In 2017 China was a leader in nitrogen fertilizer exports with a $26 \%$ share. Russia takes second place. Also, the largest exporters are Qatar, Saudi Arabia, and Canada. Leaders in the potash fertilizer export are Canada - 32\%, Russia $22 \%$, and Belarus $-17 \%$, which together make up $70 \%$ of the potash fertilizers total export. Eleven countries exporting potash fertilizers sell more than $95 \%$ of total world exports. The leader in the phosphate fertilizer export is China $-33 \%$, Russia, and the USA.

The least export-oriented sector of mineral fertilizers is nitrogen since there are many manufacturers on the market. On the other hand, the most exportoriented mineral fertilizer sector is potash. The share of exports in the production of potash fertilizers since 1993 exceeded 90\%. Over the past decade, this indicator has decreased to $80 \%$. From 1961 to 1985 , the dependence of the production of all mineral fertilizer types on export was $30 \%$. At the moment, the share of exports is growing and is now approaching $50 \%$, which can be explained by an increase in the variety of complex fertilizers and a high specialization in this area.

\section{Development factors and characteristics of the mineral fertilizer demand}

1. Correlation between the fertilizer consumption and cereal yield. Analysis of the correlation between cereal yield and fertilizer consumption per hectare of arable land shows that the countries with the highest cereal yields in the world do not coincide with the largest fertilizer consumers. The highest yields are observed in countries such as the United Arab Emirates (UAE), Kuwait, and European countries. They do not consume much fertilizer since the arable lands of these countries are relatively small. It can be concluded that the yield per hectare in the United Arab Emirates and Kuwait is the highest in the world due to the fertilizer consumption, since the land in these countries is not fertile (Figure 2).

Analysis of correlation between cereal yield and the level of fertilizer application per hectare of arable land in the most substantial mineral fertilizer consumers in the world shows that there is no direct relationship between these two indicators. Thus, China is the largest consumer of mineral fertilizers in the world, and also the leader in terms of the amount of fertilizer applied per hectare of arable land among all mineral fertilizer consumers in the world, but its yield is not as high, as in the United States or France. The Russian Federation consumes almost as many kilograms of fertilizer per hectare as China but has one of the lowest levels of cereal yield in the group (Figure 3). 


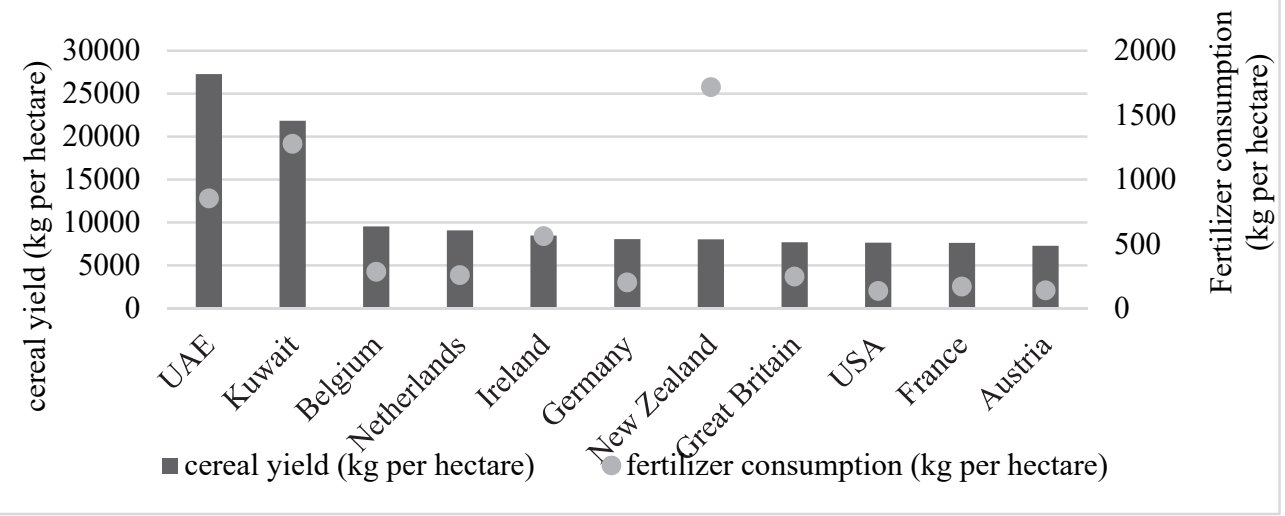

Figure 2. Fertilizer consumption (kg per hectare)

in the countries with the highest cereal yield (kg per hectare) in the world, 2017

Source: World Bank Data. https://data.worldbank.org/ (accessed: 09.07.2019).
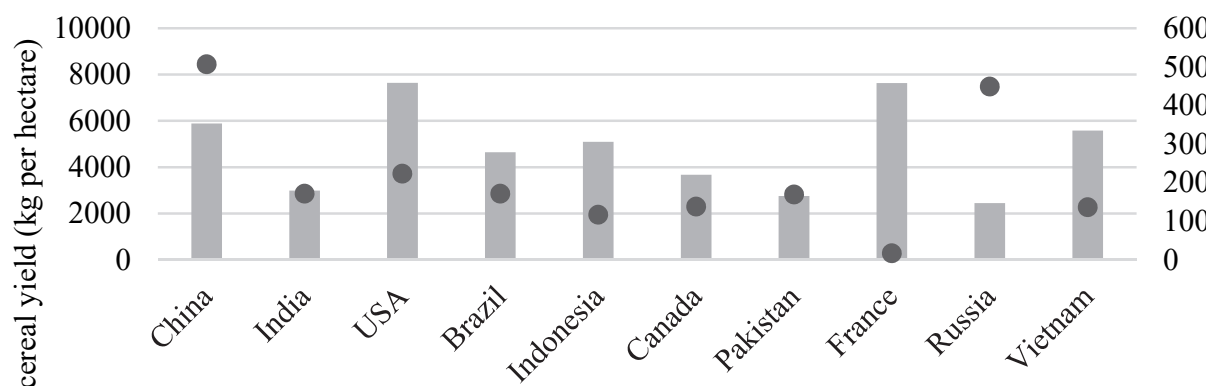

cereal yield (kg per hectare) $\quad$ fertilizer consumption ( $\mathrm{kg}$ per hectare)

Figure 3. Fertilizer consumption (kg per hectare) and cereal yield (kg per hectare) in the world's largest fertilizer consumer countries, 2017

Source: World Bank Data. https://data.worldbank.org/ (accessed: 09.07.2019).

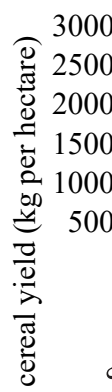

cereal yield (kg per hectare)
40000

30000

20000

10000

0

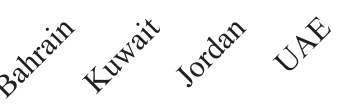

- fertilizer consumption (kg per hectare)

Figure 4. Cereal yield (kg per hectare) in the largest fertilizer consumer countries (kg per hectare) in the world, 2017 Source: World Bank Data. https://data.worldbank.org/ (accessed: 09.07.2019). 
Analysis of fertilizer consumption and yield per hectare shows that the most abundant fertilizer per hectare consumers are mostly well-developed and small countries. Most of them have soil unsuitable for agriculture: Qatar, Bahrain, Kuwait, Jordan, United Arab Emirates. Singapore is the city with the most massive $\mathrm{kg}$ per hectare fertilizer consumption, although it is a global financial center and does not specialize in the agricultural sector, same as Hong Kong (Figure 4).

2. Correlation between fertilizer consumption and arable land scale. The following logarithmical equation describes the fertilizer consumption dependency on arable land scale:

$$
\operatorname{LOG}(\text { CONSUMP) }=-0,744+0,715 * \operatorname{LOG}(\mathrm{GA}),
$$

where LOG(CONSUMP) is natural logarithm of country's fertilizer consumption volume in $\mathrm{kg}$ in 2017 year, LOG(GA) is natural logarithm of country's arable land scale (hectares). The observations include data on 98 countries. Table 1 presents the estimation of the model.

Probability tests on the fertilizer consumption and arable land scale dependency mode

\begin{tabular}{|c|c|c|c|c|}
\hline \multicolumn{5}{|c|}{$\begin{array}{l}\text { Dependent Variable: LOG(CONSUMP) } \\
\text { Method: Least Squares } \\
\text { Included observations: } 98\end{array}$} \\
\hline Variable & Coefficient & Std. Error & $t$-Statistic & Prob. \\
\hline C & -0.744471 & 0.636684 & -1.169294 & 0.2452 \\
\hline LOG(GA) & 0.715088 & 0.068521 & 10.43605 & 0.0000 \\
\hline$R$-squared & 0.531504 & \multicolumn{2}{|c|}{ Mean dependent var. } & 5.768559 \\
\hline Adjusted $R$-squared & 0.526624 & \multicolumn{2}{|c|}{ S.D. dependent var. } & 1.813134 \\
\hline S.E. of regression & 1.247478 & \multicolumn{2}{|c|}{ Akaike info criterion } & 3.300322 \\
\hline Sum squared resid. & 149.3953 & \multicolumn{2}{|c|}{ Schwarz criterion } & 3.353076 \\
\hline Log likelihood & -159.7158 & \multicolumn{2}{|c|}{ Hannan - Quinn criter. } & 3.321660 \\
\hline F-statistic & 108.9112 & \multirow{2}{*}{\multicolumn{2}{|c|}{ Durbin - Watson stat. }} & 1.870896 \\
\hline Prob(F-statistic) & 0.000000 & & & \\
\hline
\end{tabular}

Source: authors' estimates.

The correlation between fertilizer consumption and arable land scale is $52 \%$. When arable land scale (hectares) rises on $1 \%$, the fertilizer consumption increases by $0.7 \%$, with a probability of $99 \%$. The reliability tests showed the reliability of the results. The practical aspect of the model: based on this model, we can calculate the proportion of change in fertilizer consumption in a particular country and the appropriate changes in the arable land scale. Based on the analysis, it is possible to conclude the mineral fertilizer underutilization in the selected country. For the most illustrative example of the application of the model, we calculate whether the consumption of fertilizers in Russia is proportionally reduced compared to the USSR, taking into account the decrease in agricultural land.

It is clear that in the USSR, fertilizer application research was especially widely developed in agrochemistry. The post-war period is characterized by a sharp increase in the production of mineral fertilizers (Batakova, Dmitrieva, Semykina, 1973). In 1988 the production of mineral fertilizers in the USSR increased seven- 
fold. (Figure 5) Most of them were potash before 1976 and nitrogen until 1989. Between 1990 and 1991, fertilizers were not produced at all. At the moment, Russian enterprises cannot produce even half of what was produced in 1989 in the USSR. The share of mineral fertilizer production in the USSR in world production exceeded 20\% for the period from 1970 to 1988 . From 1998 to 2017 , the share of production does not grow and amounts to less than $10 \%$.

The Soviet Union sold potash and nitrogen fertilizers for export. During the period of reforms, exports ceased. Between 1993 and 2017, fertilizer exports tripled and continued to grow. Its central part is potash fertilizers. The share of Russian exports in world exports of mineral fertilizers currently equals to almost $20 \%$. In dynamics over the period under review, the share was slowly growing.

Fertilizer consumption in the USSR peaked in 1987 (Figure 5). The share of USSR consumption in world consumption of mineral fertilizers reached $20 \%$ from 1967 to 1988 . By 1994, it had fallen 15 times. Since 1994, fertilizer consumption has remained at a superficial level, even lower than in 1961.

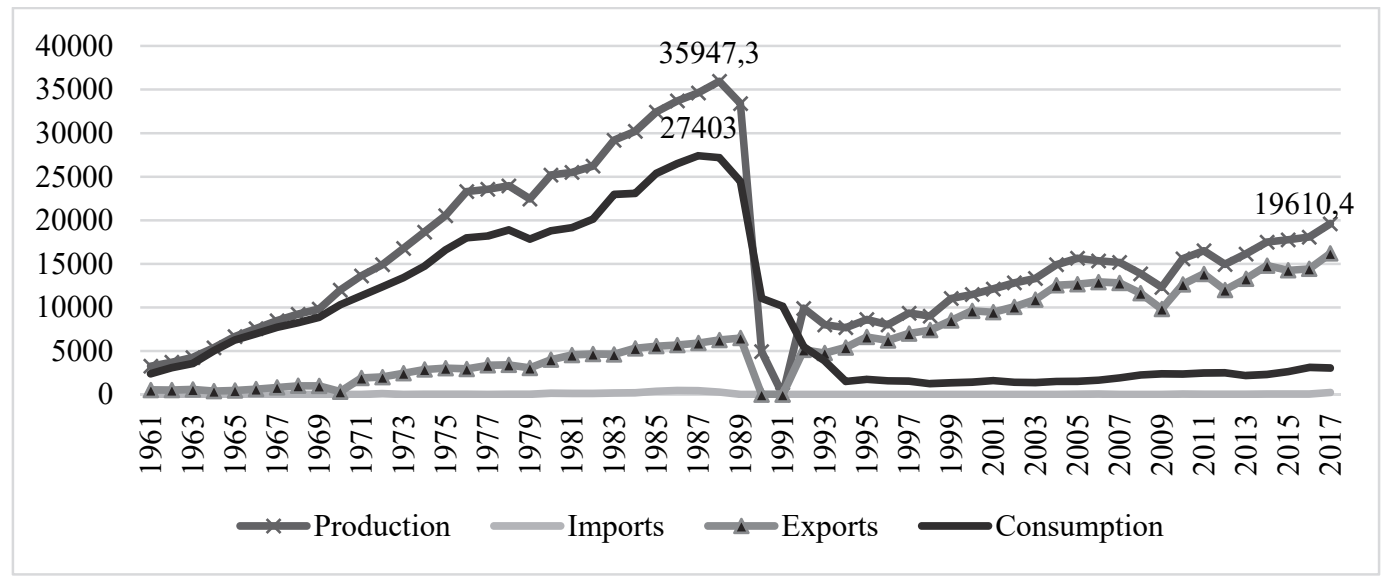

Figure 5. Dynamics of mineral fertilizer demand, supply and foreign trade in former Soviet Union and Russia, 1961-2017, ths. tons

Source: International Fertilizer Association database. http://ifadata.fertilizer.org/ucSearch.aspx (accessed: 09.07.2019).

So, as both arable land scale and fertilizer consumption decreased since 1991 in Russia, it is possible to use the estimated model and find out if fertilizer are under consumed. The initial data and the calculation results are shown in Table 2.

Analysis of changes in fertilizer consumption in the USSR and Russia in 1989 and 2017

\begin{tabular}{lcc}
\hline & Arable land scale (km sq.) & consumption (ths. tons) \\
\hline Russia (2017) & 2177218,2 & 2832,2 \\
USSR (1989) & 6001000,0 & 24474,0 \\
Actual decrease & $-64 \%$ & $-88 \%$ \\
Estimated decrease & $-64 \%$ & $-45 \%$ \\
Estimated fertilizer consumption & - & 13401,8 \\
Under consumption & - & 10569,6 \\
\hline
\end{tabular}

Source: authors' estimates. 
Since the model is one-factor and determine the dependent variable by $50 \%$, errors are inevitable in this calculation.

\section{Conclusion}

The main identified trends in the global market of mineral fertilizers: growing demand, moving production closer to the consumer, from developed countries to developing ones. The following mineral fertilizer market-makers in 2017 have been determined: the world's largest producers are China, Russia, and India; the world's largest importers are the USA, Brazil, and India; the world's largest fertilizer consumers $(\mathrm{kg})$ are China, India and the USA; the countries with the most effective mineral fertilizer application (with the highest cereal yield kg per hectare) are UAE, Kuwait, Belgium; the world's largest fertilizer consumers (kg per hectare) are Singapore, Qatar, Hong Kong. Thus, countries pursuing the aim of increasing yield are not likely to achieve it by gaining aggregate consumption, since there is no direct relationship between these indicators. So the paper shows where in the world the mineral fertilizer consumption concentrates except countries with the highest aggregate consumption.

While is no direct correlation between fertilizer consumption and cereal yield, but the correlation between fertilizer consumption and arable land scale is $52 \%$. When arable land scale (hectares) rises on $1 \%$, the fertilizer consumption increases by $0.7 \%$, with a probability of $99 \%$. USSR was the most influential leader in both mineral fertilizer consumption and production. It also had the most significant arable land scale in the world. The case is that after the reforms period, both consumption and arable land scale have reduced. Nowadays, Russia is one of the biggest producers and exporters but unfortunately does not consume its alternative value of fertilizer. According to this model, Russia under consuming 10569 thousand tons of its estimated volume: Russia's arable land scale cut down on 64\%, and fertilizer consumption decreased by $88 \%$, but estimations show it should have been fallen by only $45 \%$.

\section{References}

Batakova, V.M., Dmitrieva, G.S., \& Semykina, G.V. (1973). Khimizatsiya sel'skogo khozyaistva [Chemicalization of agriculture]. Moscow: Nauch.-issled. in-t tekhn.-ekon. issledovanii NIITEKhIM. (In Russ.)

Bleiman, N., \& Burkov, A. (2017). Plan mineral'nogo nastupleniya [Mineral attack plan]. $R B C+, 181(2678), 1-4$. (In Russ.)

Falina, N.V., \& Dyukarev, D.O. (2016). Mirovoi rynok mineral'nykh udobrenii [The global market for mineral fertilizers]. Economics, 1(10), 83-86. (In Russ.)

Food and agriculture organization of the UN. (2017). World fertilizer trends and outlook to 2020. FAO, Rome, Italy, 2-4.

International fertilizer association. (2019). Outlook summary reports. Montreal. Retrieved from https://www.ifastat.org/market-outlooks (accessed: 09.07.2019).

Lyskova, I.V., Lyskova, T.V., \& Mazurova, S.V. (2018). Influence of mineral fertilizers on productivity and grain quality in spring wheat Iren. Zernobobovye i krupyanye kul'tury, 4(28), 141-147. doi: 10.24411/2309-348X-2018-11064. (In Russ.) 
Nazarbek, U.B. (2013). Analiz sostoyaniya mirovogo rynka mineral'nyh udobrenij [Analysis of the state of the global market of mineral fertilizers] Aktual'nye problemy gumanitarnyh $i$ estestvennyh nauk, (2-1), 7-12. (In Russ.)

Rodionova, I.A. (2010). Mirovaya ekonomika industrial'nyj sector [World Economy Industrial Sector]: study guide (pp. 482-494). Moscow: RUDN University. (In Russ.)

Semina, Yu.A. (2016). Sostoyanie rynka ammiachnoj selitry v Rossii v period 2015-2016 gg. [The state of the market of ammonium nitrate in Russia in the period 2015-2016]. Vestnik himicheskoj promyshlennosti NIITEKHIM. Retrieved from http://vestkhimprom.ru/ (In Russ.)

Volkova, A.V. (2015). Rynok mineral'nykh udobrenii [Mineral fertilizer market]. Moscow: Natsional'nyi issledovatel'skii universitet "Vysshaya shkola ekonomiki". Retrieved from https://dcenter.hse.ru/data/2015/12/22/1132768850/IV\%20кв\%202015.pdf (In Russ.)

Yakovleva, A. (2017). Mirovoi rynok mineral'nykh udobrenii [World mineral fertilizer market]. AgroSnabForum, (3), 54-57. (In Russ.)

\title{
Article history:
}

Received: 15 September 2019

Revised: 30 October 2019

Accepted: 29 November 2019

\section{For citation:}

Dyuzheva, N.V., \& Tinkova, A.A. (2019). Mineral fertilizer market consumption trends. RUDN Journal of Economics, 27(4), 722-731. http://dx.doi.org/10.22363/2313-2329-201927-4-722-731

\section{Bio notes:}

Natalya V. Dyuzheva, Candidate of Economics, International Economic Relations Department, People's Friendship University of Russia (RUDN University). E-mail: dioujeva@ yandex.ru

Arina A. Tinkova, $1^{\text {st }}$-year master of Economics, International Economic Relations Department, Peoples’ Friendship University of Russia (RUDN University). E-mail: tinkova_aa@ pfur.ru

Научная статья

\section{Тенденции спроса}

\section{на мировом рынке минеральных удобрений}

\author{
Н.В. Дюжева, А.А. Тинькова \\ Российский университет дружбы народов, \\ Российская Федерация, 117198, Москва, ул. Миклухо-Маклая, 6
}

В исследовании проводится анализ тенденций на мировом рынке минеральных удобрений. Цель - определить факторы, влияющие на потребление удобрений. В круг поставленных задач входят анализ динамики и структуры спроса, предложения, внешней торговли, неценовых факторов и характеристик и прогноз их развития; анализ взаимосвязей между потреблением удобрений, площадью посевных площадей, урожайностью зерновых; изучение феномена потребления минеральных удобрений в России. 
В статье даны ответы на вопросы, где сосредоточено потребление удобрений и почему именно там. Выявленными лидерами по производству на рынке являются Китай и Россия; мировые потребители - Бразилия, Индия, Китай и США. Страны с самым высоким урожаем зерновых в мире не совпадают с крупнейшими странами - потребителями удобрений. Урожайность зерновых и уровень внесения удобрений на гектар посевных площадей в крупнейших странах - потребителях минеральных удобрений напрямую не связаны. Страны с самой высокой урожайностью зерновых в основном хорошо развиты, но у них относительно небольшие посевные площади. У большинства из них почва не подходит для сельского хозяйства. Когда посевная площадь (га) увеличивается на $1 \%$, потребление удобрений увеличивается на $0,7 \%$ с вероятностью $99 \%$. По этой модели Россия недостаточно потребляет на 10569 т от расчетного объема. Данные были классифицированы в программе Excel и проанализированы с помощью программного обеспечения эконометрического моделирования Eviews.

Ключевые слова: минеральные удобрения, мировой рынок, урожайность, внешняя торговля, потребление

\section{История статьи:}

Дата поступления в редакцию: 15 сентября 2019

Дата проверки: 30 октября 2019

Дата принятия к печати: 29 ноября 2019

\section{Для цитирования:}

Dyuzheva N.V., Tinkova A.A. Mineral fertilizer market consumption trends (Тенденции спроса на мировом рынке минеральных удобрений) // Вестник Российского университета дружбы народов. Серия: Экономика. 2019. Т. 27. № 4. С. 722-731. http:// dx.doi.org/10.22363/2313-2329-2019-27-4-722-731

\section{Сведения об авторах:}

Дюжева Наталья Валериевна, кандидат экономических наук, доцент кафедры международных экономических отношений, Российский университет дружбы народов. E-mail: dioujeva@yandex.ru

Тинькова Арина Александрова, магистрант экономики, кафедра международных экономических отношений, Российский университет дружбы народов. E-mail: tinkova_aa@pfur.ru 